\title{
A Cascade Multilevel Z-Source Inverter for Photovoltaic System
}

\author{
Thirumalini P, R. Arulmozhiyal, M Murali* \\ Department of Electrical \& Electronics Sona College of Technology, Salem, India \\ *Corresponding author, e-mail: tirumalini@gmail.com, arulmozhiyal@gmail.com, \\ muralimunraji@gmail.com
}

\begin{abstract}
This paper describes a multilevel Z-source inverter for solar photovoltaic applications. The conventional power conversion topology performs either buck or boost the input voltage for non linear load depending upon duty ratio and modulation index in a multiple stage conversion with the help of impedance source passive network ( $L$ and $C$ ), which is usually known as Z-Source, which couples the $n$ level source with input to the power source and increase the power efficiency. The multilevel $z$ network capabilities of inverter are operated in the shoot through state of duty cycle and it acts as a filter to reduces the level of harmonics, stabilize power factor and to increase the output AC voltage range of inverter. To overcome further harmonics, multilevel level operation z source inverter compensates the fundamental level of harmonic in renewable. Proposed work as a whole involves the simulation part to design multilevel inverter. The output of the simulation is obtained by Simulink model using MATLAB.
\end{abstract}

Keywords: Z source inverter, Photo voltaic system, total harmonic distortion (THD)

Copyright ( 2015 Institute of Advanced Engineering and Science. All rights reserved.

\section{Introduction}

Renewable energy sources naturally available, such as wind, photovoltaic (PV) and fuel cell are becoming more needs for industrial and residential applications. Nowadays, Photovoltaic cells are used in wide several areas due to it's very often maintenance, free from pollution and zero fuel cost. In present scenario the energy generation through PV cell has grown rapidly from $40 \%$ to $45 \%$ per annum over the past 20 years that is mostly because of the costs in PV cells thanks nano-technology field which has reduced PV panels as for cost and area structure is concern [1-2]. The converter and inverter are other prominent area where has solar and wind energy generation is being processed used by users community. Due to recent developments in power electronics technology inverter and converter grows leaps and bounds in terms of efficiency. Z source type of inverter performs efficient power transfer between dc to ac. In a conventional $Z$ source inverter the two switches of the same-phase leg are be triggered at the same time because this cause a short circuit which would destroy the switches life time [3].

In the centralized configuration, a number of PV modules are connected $Z$ source inverter using inductance and capacitance values [4-5]. The $Z$ source inverter solution employs the opposite approach by using a small inverter for individual MPP tracking of each PV module, maximizing possible energy harvesting. Therefore, reducing or even losing the output of a single $z$ source inverter has a minimal impact on the overall system performance. However, the main drawback of the inverter concept is a higher initial equipment cost per peak watt. In PV systems, such as residential applications, the inverter price has less effect on the overall cost, and therefore, $Z$ source inverters are the preferred solution. As the price of $Z$ source inverter comes down, this technology will be more attractive in other applications [6].

In addition, the reliability of the inverter is for effective solar power generation due to shoot through state caused in Z source parameters by Electro Magnetic Interference (EMI) noise can destroy the circuit for longer periods [7]. The appropriate switching permits the addition of capacitor voltages or inductor in the output port. This topology results in high voltage generation without stressing the semiconductors components. $Z$ source inverter has advantages in multi-levels has the following merit: (i) sinusoidal output waveform, (ii) a efficient filter size and (iii) a minimized EMI. 
The main advantage of using $Z$ source inverter is to reduce the Total Harmonic Distortion (THD) from source especially like third and seventh order harmonics in the output voltage because of multiple voltage levels switching semiconductor reduces stress on the switching devices [8]. Multi generation PWM strategy is a widely adopted in modulating strategy for inverter. It is like the sinusoidal PWM strategy [9]. Multicarrier PWM is one in which, several cycle of triangular carrier signals are compared with one cycle of sinusoidal modulating signal. The number of carriers are necessary to produce $m$-level output is $(m-1)$. All carriers have the similar peak to peak amplitude Ac and frequency fc [10].

The main objective of this paper is to implement multilevel z-source inverter with the grid interfacing solar power generation system as blocks shown in Figure 1. The function of multilevel z-source inverter is to synthesis a decided output ac voltage from several levels of dc input voltage with minimum harmonic distortion. The magnitude of output ac voltage of conventional inverter is limited to dc source voltage and with more harmonic distortion and this limitation can be resolved by cascaded multilevel z-source inverter. The proposed multilevel zsource inverter shoots through to boost dc link voltage. A comparison analysis has been made with conventional z-source and multilevel z-source network in matlab simulink environment and its performance has been analysed using real time controller.

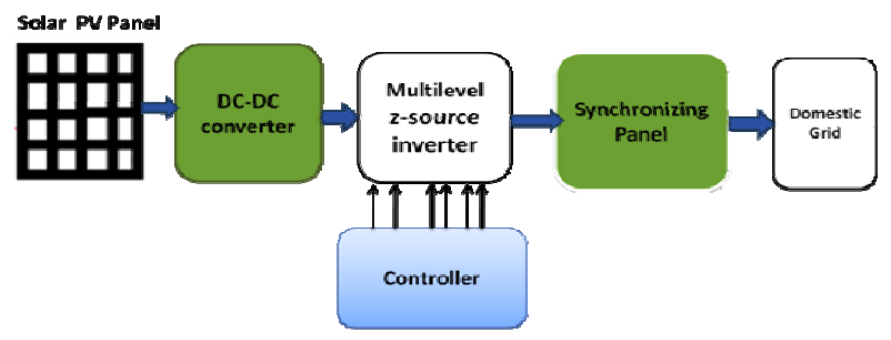

Figure 1. Block diagram of proposed system

\section{Photovoltaic Cell}

The equivalent model of a photovoltaic cell can be represented by Figure 2 as shown below. To obtain maximum power from solar are connected in series or in parallel, which forms a module. Again, these types of modules are connected in parallel or in series to get required voltage and current. The characteristics of PV cell can be derived using the equation given below.

$$
I=I p v-I o\left[e^{\frac{V+R s I}{V t a}}-1\right]-\left(\frac{V+R s I}{R p}\right)
$$

Where $I_{p v}=$ photo voltaic current, $I_{0}=$ Nil or saturation current, $V_{t}=N_{s} k T / q$, array thermal voltage, $\mathrm{N}_{\mathrm{s}}=\mathrm{pv}$ cell connected in series, $\mathrm{T}=\mathrm{PV}$ panel diode temperature, $\mathrm{k}=$ constant of Boltzmann, $q=$ electron charge, $R_{s}=$ equivalent resistance of the series connected array, $R_{p}=$ equivalent I resistance of parallel connected array, $a=$ ideality constant of diode. The resistance connected in series $\left(R_{s}\right)$ can be regulated from the value of shunt resistance $R_{p}$ either high or low when compared to the value of series resistance $R_{s}$.

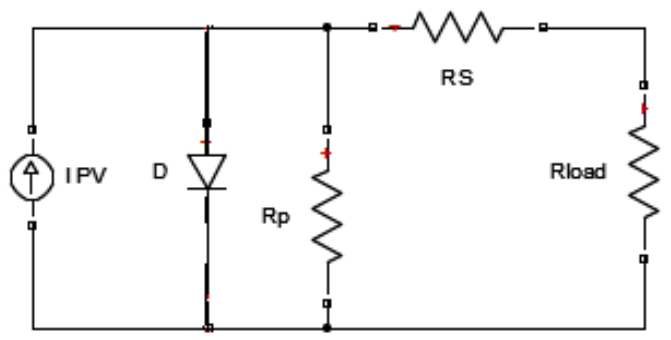

Figure 2. Photo Voltaic cell equivalent circuit

TELKOMNIKA Vol. 16, №. 3, December 2015 : $473-479$ 
The saturation current generated by the light is linearly depends upon the solar irradiation from sun and temperature which, influence the generation of photovoltaic current in the solar cell which is derived by the following equation.

$$
\mathrm{Ipv}=\left[\mathrm{Ipv}, \mathrm{n}+\mathrm{K}_{\mathrm{b}} \Delta \mathrm{T}\right] \frac{\mathrm{G}}{\mathrm{Gn}}
$$

Where $I_{p v}=$ current generation of photo voltaic cell at the nominal condition $\left(25^{\circ} \mathrm{C}\right.$ and $\left.\mathrm{W} / \mathrm{m}^{2}\right), \Delta \mathrm{T}$ $=\mathrm{T}-\mathrm{Tn}, \mathrm{T}=$ temperature in actual condition $[\mathrm{K}], \mathrm{T}_{\mathrm{n}}=$ nominal temperature $[\mathrm{K}], \mathrm{K}_{\mathrm{l}}=$ current coefficients of $P V$ cell, $G=$ irradiation of the device surface $\left[W / m^{2}\right], G_{n}=$ nominal irradiation.

\subsection{DC - DC Boost Converter}

The power generated by the PV panel fed in to converter for domestic user applications. The power obtained from PV source is unregulated and required to maintain optimum outputs from the converter. The energy will fed to the load with the dual stage power electronic system comprising as converting medium to boost power as type of DC-DC converter and inverter. In order to maintain a constant voltage to the load, a DC-DC step up converter is introduced in process of power generation. The Photovoltaic array and the inverter needs maintain constant power output to domestic consumers. The conduction mode of the DC-DC converter can be given by the following equation.

$$
\frac{\mathrm{Vo}}{\mathrm{Vin}}=\frac{1}{1-\mathrm{D}}
$$

Where $\mathrm{D}=$ duty cycle,

The value of the duty cycle $D$ will always between 0 and 1 and hence it is important to maintain the output voltage higher than the input voltage in magnitude

\section{Z-Source Inverter}

An Impedance inverter is termed as Z-source inverter and through its control method to implement operation of dc-to-ac power conversion. The Z-source inverter is a unique resistance capacitance and inductance network to deliver maximum power form solar modules and an inverter circuit, the conventional $Z$ source inverter has drawbacks of more harmonic distortion in power outputs voltage sag and swell. Thus, to overcome drawbacks in conventional $Z$ source inverter a modified multilevel converter is proposed in this topic.

The traditional converter failed to have filter circuits to reduce harmonics distortion. The Z-source inverter overcomes the theoretical and hypothetical barriers and restrictions of the traditional vsi and csi inverters as it provides efficient power conversion techniques. The Zsource concept is also a bidirectional capability inverting circuit applied to all dc-to-ac, ac-to-dc, ac-to-ac, and dc-to-dc power conversion with less quality issues. Z-source inverter for dc-ac power conversion is efficient applications in fuel cell power generation.

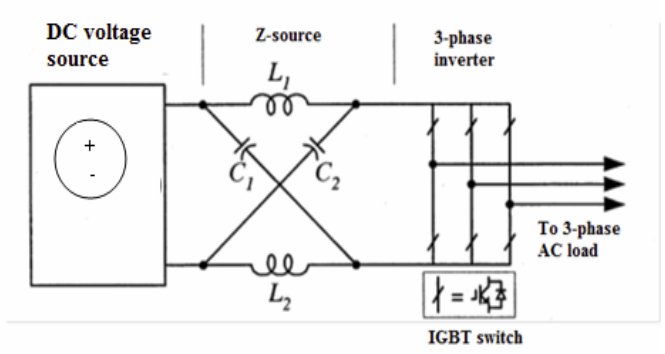

Figure 3. Z source Inverter Circuit configuration

The Z source-resistance-capacitance-inductance network is to couple the inverter circuit topology in multiple cascaded configurations to the link with power source and thus providing 
unique concept cascaded multilevel feature as shown in Figure 3. The control strategies with the insertion of shoot-through states in Z-source inverter with LC filter is analyzed. There were exists two conventional inverters, voltage-source inverter (VSI) and current-source converters (CSI), to perform either rectifying or inverting operation depending on power flow directions. There are some limitations in the quality of power output with higher Total Harmonic Distortion (THD).

Total harmonics distortion affects overall output of system. In specific third distortion is standard frequency of harmonics which is generates three times of fundamental frequency harmonics in the system it more severe than to create EMI problems in switching patterns; five times the fundamental is fifth harmonic leads over heating with sag and swell issues. The harmonics in a system can be defined generally using from the Equation (4).

$$
f_{h}=h f_{a c}
$$

Where fh is the number of harmonics and fac is the frequency of fundamental system harmonics. In domestic interface power lines higher order harmonics are not given much importance which does create harm to system. The important and harm creating harmonics in system are $3^{\text {rd }}, 5$ th, 7 th, 9th, $11^{\text {th }}$ and $13^{\text {th }}$. The harmonics waveforms in general is given in Equation (5).

$$
v_{n}=v_{r n} \sin (\mathrm{n} \omega \mathrm{t})
$$

Where, Vrn is the voltage in rms of particular harmonic frequency (harmonic or power line).

\subsection{Operation of Z Source Inverter}

The Z-source network operates in "shoot-through zero state" which is possible to provide the unique boost-buck operation in the aspect of inverter [6]. The Z-source inverter is operated in two modes which are briefed below.

1) Shoot through mode: In the shoot-through state, switch $S 7$ is triggered and diode $\mathrm{Da}$ is off state. The equivalent circuit of shows the shoot-through state with corresponding ON and OFF switches is shown in Figure 4. The operational analysis is expressed as:

$$
\begin{aligned}
& \mathrm{V}_{\mathrm{L}}=\mathrm{V}_{\mathrm{C}} \\
& \mathrm{V}_{\mathrm{dc}}=\mathrm{V}_{\mathrm{L}}-\mathrm{V}_{\mathrm{C}}
\end{aligned}
$$

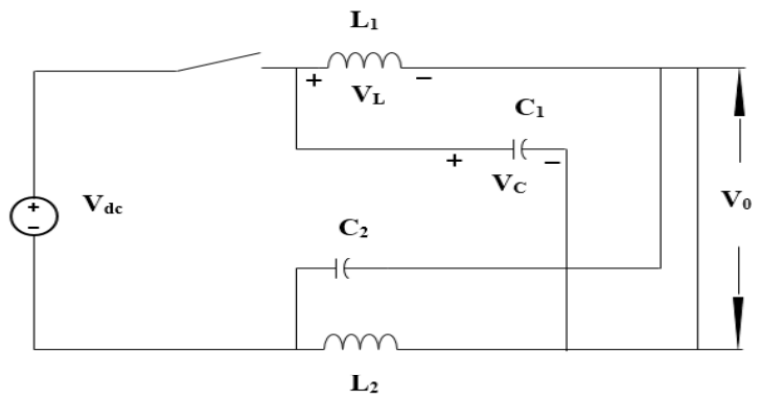

Figure 4. Circuit of shoot through mode

2) Non shoot through mode: In non-shoot-through mode switch $S 7$ is triggered and as with capacitance and inductance in parallel as shown in Figure 5. Output of LC filter network and inductor voltage can be calculated as:

$$
\text { Vin }=V_{c}-V_{L}
$$


The boost coefficient factor $B$ is determined by the Modulation Index (MI). The shootthrough zero state is affects PWM control of the inverter. As it generates equivalently the zero voltage to the load terminal and the creates a shoot- through period varying by modulation index.

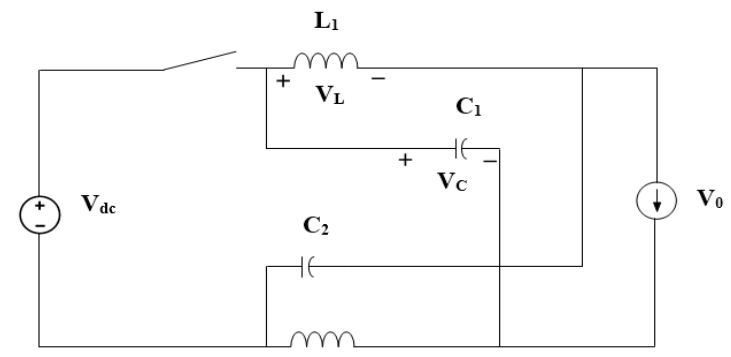

$\mathbf{L}_{2}$

Figure 5. Circuit of shoot through mode

In Z-source inverter is cascaded in to two levels to design a multilevel-Z-source inverter. Advantages of multi level Z Source Inverter are: (i) either increase or decrease in the voltage for PV energy process to the load, (ii) as it eliminates order harmonics leads to reduces the mismatch of switching patterns and EMI distortions, (iii) provides ride-through during power quality issues like voltage sags and swell without need for additional circuits, (iv) improved domestic user power factor (PFC), (v) reduced harmonic current and distortion, (vi) reduced common-mode voltage, (vii) cheaper in implementation, (viii) improves reliability and (ix) highly efficient for cascaded structure [7].

\section{Simulation Results}

The cascaded stage multilevel $Z$ source inverter was simulated using MATLAB/SIMULINK tool. The PV cell was designed and simulated with the help of its equivalent circuit. Temperature and irradiation were considered as the changing parameters to change the output of the solar cell. Two PV cells of $12 \mathrm{~V}$ and $24 \mathrm{~V}$ were taken as input for the multilevel $Z$ source inverter configuration as per Figure 2.

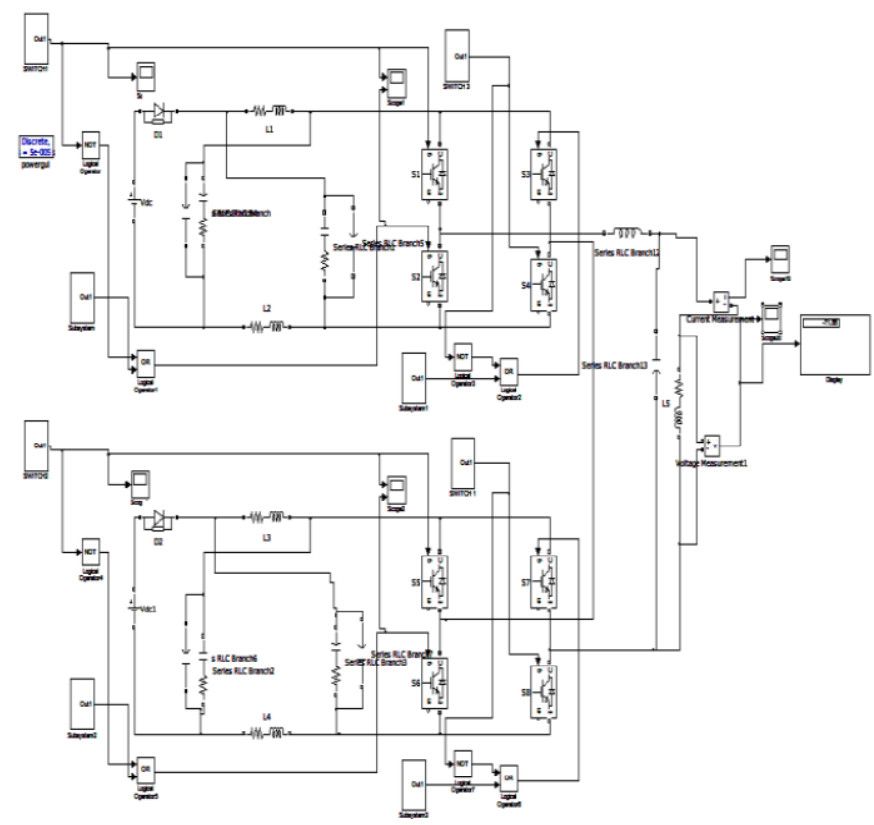

Figure 6. MATLAB circuit for multilevel $Z$ source inverter 
The switching circuit consists of reverse blocking switches using MOSFETs and diodes which are taken from simulink library. A two winding $12 \mathrm{~V} / 230 \mathrm{~V}$ is used to connect the multilevel $Z$ source inverter to the load side. Resistive load was considered for the simulation and the switching sequence were provided according to the operation described above. A $50 \mathrm{~Hz}, 20 \mathrm{~V}$ peak voltage waveform was obtained at inverter output. The simulation diagram of multilevel $Z$ source inverter is shown in Figure 6 and the output waveforms are shown in Figure $7 \& 8$. The output waveform represents less distortion compared with $Z$ source inverter and effective THD is measured in Table1

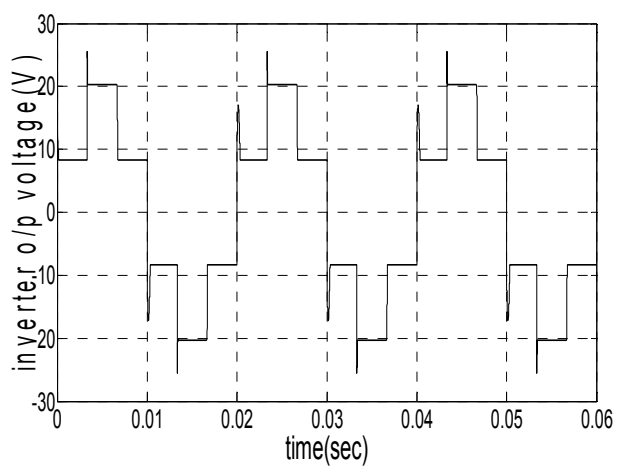

Figure 8. Output current of multilevel z-source inverter

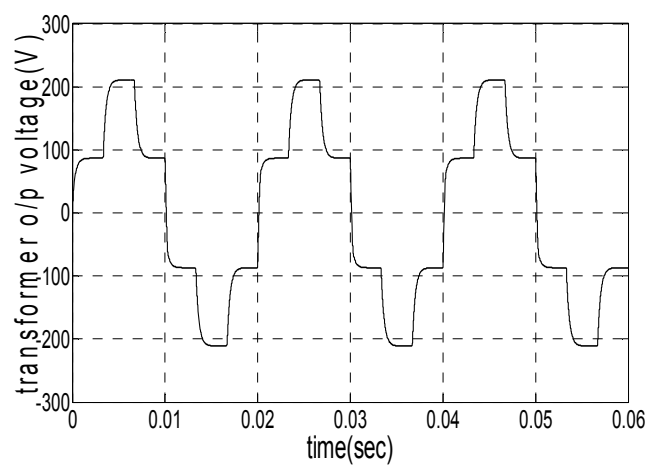

Figure 9. Output voltage of multilevel z-source inverter

Table 1. THD analysis of Z-source inverters

\begin{tabular}{llll}
\hline S.NO & INVERTER & $\begin{array}{l}\text { THD\% } \\
\text { (VOLTAGE) }\end{array}$ & $\begin{array}{l}\text { THD\% } \\
\text { (CURRENT) }\end{array}$ \\
\hline 1. & Z-phase inverter & $18.59 \%$ & $18.80 \%$ \\
2. & Multilevel z -source inverter & $10.89 \%$ & $4.88 \%$ \\
\hline
\end{tabular}

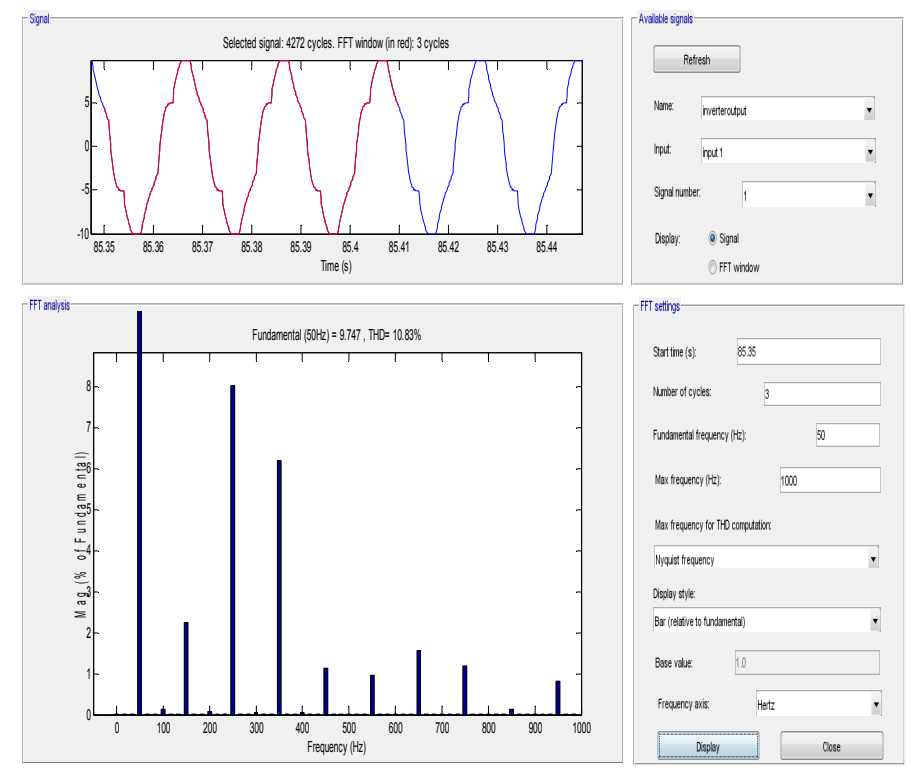

The voltage and current harmonics range in three phase inverter is $18.59 \%$ and $18.80 \%$ respectively. Similarly the voltage and current harmonics range in z-source inverter is $10.89 \%$ and $10.85 \%$ respectively. By this, the multi $z$-source inverter finds to be more efficient when compared with single stage $z$ source inverter.

TELKOMNIKA Vol. 16, No. 3, December 2015 : 473 - 479 


\section{Conclusion}

A multilevel $Z$ source inverter for PV systems was simulated using MATLAB/SIMULINK tool. This multi-rated source inverter can have an arbitrary number of PV sources and is able to obtain the maximum possible power of each delivery independently. The PV sources can be of different electrical parameters and working conditions. The multilevel $Z$ source inverter is responsible for boosting the voltage to required output level. $Z$ network capacitors and inductor on primary side in inverter realize soft-switching operation. The control scheme and the switching algorithm of the proposed inverter were described. The output of inverter is validated with THD using MATLAB FFT analysis. THD of the output waveform was reduced to $10.85 \%$ using filter circuits.

\section{References}

[1] Fang Zheng Peng. Z-Source Inverter. IEEE Transactions On Industry Applications. 2003; 39(2).

[2] The Renianssance of Solar Power Panels Energy By Olatunji. Adetunji.

[3] Sudhir Ranjan, Sushma Gupta, Ganga Agnihotri. International Journal of Chem Tech Research CODEN (USA). 2013; 5(2): 993-1002.

[4] Suresh L, GRS Naga Kumar, MV Sudarsan, K Rajesh. Department of Electrical \& Electronics Engineering. Vignan's Lara Institute of Technology \& Science. Vadlamudi, India.

[5] Muhammad H Rashid. Power Electronics Circuits Devices and Applications. $2^{\text {nd }}$ Edn. Englewood Cliffs, N.J: Prentice Hall. 1993.

[6] Umesh Sinha. Network Analysis and Synthesis. Satya prakasan. $5^{\text {th }}$ Edn. New Delhi: Incorporating Tech India Publications. 1994.

[7] Robert L, Boylestad Louis Nashelsky. Electronics Devices and Circuit Theory. New Delhi: Prentice Hall of India. 2000.

[8] Sajith Shaik, I Raghavendar. Power Quality Improvement of Three Phase Four Wire Distribution System Using VSC With a Zig-Zag Transformer. International Journal of Engineering Research and Applications (IJERA). 2012; 2(6).

[9] Nisha KCR, TN Basavaraj. Implementation of Impedance Source Inverter System for Photovoltaic Applications. Electrical \& Electronics Department, Sathyabama University, Chennai, India. Electronics \& Communication Department, New Horizon College Of Engineering, Bangalore, India.

[10] Power Factor Correction of Non-Linear Loads Employing a Single Phase Active Power Filter: Control Strategy, Design Methodology and Experimentation. Fabiana Pottker and Ivo Barbi Federal University of Santa Catarina. Department of Electrical Engineering. Power Electronics Institute. Florianopolis SC - Brazil.

[11] Kanchan Chaturvedi, Dr Amita Mahor, Anurag Dhar Dwivedi. Active Power Filter Techniques for Harmonics Suppression in Non Linear Loads. Department of Electrical \& Electronics Engineering. N.R.I. Bhopal (M.P.) India. 